\title{
Difficulties in College Algebra of Freshmen Students at the University of Eastern Philippines: Basis for Modular Construction
}

\author{
Olga D. G. Unay, Ida E. Esquierdo, May Jane B. Calpa, Danilo C. Basista, \\ Emilia Vanessa Selena B. Pinca, Fel B. Muncada Jr. \\ Department Mathematics, College of Science, University of Eastern Philippines, Catarman, Philippines \\ Email: ounay2873@gmail.com, esquierdoida@gmail.com
}

Received 10 April 2016; accepted 25 April 2016; published 29 April 2016

Copyright (C) 2016 by authors and OALib.

This work is licensed under the Creative Commons Attribution International License (CC BY). http://creativecommons.org/licenses/by/4.0/

(c) (i) Open Access

\begin{abstract}
A strong grasp in mathematics is a key factor in ensuring success in mathematics education. This study tried to identify the difficulties in College Algebra of freshmen students in the University of Eastern Philippines during the school year 2013-2014 as basis for modular construction. The performance level was determined by giving a teacher made test to find out the skill areas students were deficient. The causes of their deficiencies were traced as basis for constructing modules. In this study, the descriptive normative method of research was used where the College of Science freshmen students were the respondents. The performance level of the students in College Algebra based on teacher made test given by the researchers was very low, the overall total score of total score of the given items answered correctly by the students was 324 , the average was 77.16 and the mean performance was 26.34 . The result showed that the mean performance was 26.34 . The result showed that the mean performance was very low without mastery. The students had almost no background on the seven areas which resulted to their very low performance. They lacked knowledge, competency and skills in answering questions especially in solving the application of word problems which obtained a mean score of 2.99 , followed by special product and factoring, equations and radicals. The result of the study showed that the students were deficient in the application of word problems, special product and factoring, equations and radicals.
\end{abstract}

\section{Keywords}

Difficulties, College Algebra, Modular Construction, Descriptive Normative

Subject Areas: Education

How to cite this paper: Unay, O.D.G., Esquierdo, I.E., Calpa, M.J.B., Basista, D.C., Pinca, E.V.S.B. and Muncada Jr., F.B. (2016) Difficulties in College Algebra of Freshmen Students at the University of Eastern Philippines: Basis for Modular Construction. Open Access Library Journal, 3: e2597. http://dx.doi.org/10.4236/oalib.1102597 


\section{Introduction}

Mathematics plays a major role in a number of scientific fields such as biology, meteorology, engineering, physics, medical services, and many others. According to Carl Friedrich Gauss, mathematics is a queen of all sciences because it is the main driving force behind scientific discovery [1]. Behind any scientific inventions and discoveries, mathematics plays a vital role to support any claim of discovery. To realize this claim, it is imperative that the teacher's knowledge of a subject matter and his/her ability to deliver to the students is needed in the teaching and learning process. It is also the teacher's task to device instructional materials for his or her students for a more effective way of teaching the subject [2].

Students cannot simply receive knowledge from the teacher and understand it in the way that the teacher thinks about it. As Lambdin states: “A teacher's goal is to help students understand mathematics; yet understanding is something that one cannot teach directly. No matter how kindly, clearly, patiently, or slowly teachers explain, they cannot make students understand" [3].

Freshmen College students could hardly get over the difficulty of college algebra. Oftentimes, researchers or even experts wanted to figure out the different causes of difficulty in any subject to be able to source out any solutions for ease of learning specifically college algebra [4]. The researchers try to ask college freshmen students as to the difficulty of the subject, but most students have a negative attitude towards the subject. Hence, this study tried to assess their difficulty in order to be the basis of the department to construct a module intended for college freshmen students.

\section{Methodology}

This study was conducted in the University of Eastern Philippines in the College of Science whose respondents were the college freshmen students enrolled in College Algebra subject in the school year 2013-2014. This was conducted as basis for modular construction.

This study employed the descriptive normative method of research. The respondents were the college freshmen students enrolled in college algebra in the first semester school year 2013-2014 which were composed of 109 college freshmen students enrolled.

The students were given a teacher made test to determine the performance level of the students in the subject. A survey questionnaire was also used to gather the data. The questionnaire composed of questions of the difficulties encountered by the students in learning college algebra on each topic. Students were also asked about their difficulties encountered in learning the subject on the part of their teachers. After all the questionnaires were retrieved, the data were tallied and tabulated, and further statistically treated using frequencies and mean scores to answer the specific questions.

\section{Results and Discussion}

Based on the results, it has been found out that the performance level of the students in College algebra based on the teacher made test was very low which was revealed on the overall total score of the given items that were answered correctly by the students was 324. The average was 77.16 and the mean performance was 26.34 . The result showed that the mean performance of the students was very low without mastery. The students had almost no background on the seven areas which resulted to their very low performance as reflected on Table 1.

As reflected on the above table, students were lack of knowledge, competency and skills in answering questions specially in the application of solving word problems which obtained a mean score of 2.99, followed by special product and factoring with mean scores of 2.951 and 2.893, equations of 1.883, and radicals of 1.97.

Students were also asked questions about their difficulties encountered in learning the subject on the part of their teacher as shown in Table 2. Results showed that their mastery of learning the seven areas was affected because their teachers gave very long assignments which have a mean score of 2.65 as reflected on the table below. This implied that students cannot do very well in doing their assignments because of the lack of instructional materials which has a mean score of 1.835 and do not also have enough reference material having a mean score of 1.757. These findings confirmed on the study of Okello that indeed most of the students had difficulty in mathematics and gave varied reasons why this was the case. Lack of persistence, determination and confidence in oneself were some of the reasons established as the main obstacles that hinder most students from enjoying an otherwise exciting and interesting course [5]. 
Table 1. On the part of the students.

\begin{tabular}{|c|c|c|c|c|}
\hline 1. I don't understand: & Difficult (3) & Moderate (2) & Easy (1) & Mean \\
\hline 1.1 Exponents & 0.1068 & 0.2136 & 0.6796 & 1.4272 \\
\hline 1.2 Radicals & 0.2427 & 0.4854 & 0.2018 & 1.9709 \\
\hline 1.3 Equation (linear and quadratic) & 0.1942 & 0.4951 & 0.3111 & 1.8835 \\
\hline 1.4 Operation on algebraic equation & 0.1068 & 0.6408 & 0.2524 & 1.8544 \\
\hline 1.5 Special product & 0.2816 & 0.5437 & 0.1748 & 2.9515 \\
\hline 1.6 Factoring & 0.2621 & 0.5631 & 0.1748 & 2.8932 \\
\hline 1.7 Application of word problems & 0.7087 & 0.1845 & 0.1068 & 2.9942 \\
\hline 2. I'm very slow in four fundamental operation & 0.0485 & 0.2427 & 0.7087 & \\
\hline 3. I don't know the fundamental operation to be used in word problem & 0.6408 & 0.2039 & 0.1748 & 2.4272 \\
\hline 4. I'm very slow in comprehension & 0.5631 & 0.3398 & 0.0970 & 2.1553 \\
\hline 5. I hate mathematics & 0.1262 & 0.7087 & 0.1650 & 2.3398 \\
\hline 6. I don’t study my lessons & 0.2233 & 0.6602 & 0.1165 & 2.7767 \\
\hline 7. I'm always absent & 0.0970 & 0.3204 & 0.5825 & 1.8058 \\
\hline 8. I have poor study habits & 0.0874 & 0.7670 & 0.1456 & 2.2039 \\
\hline 9. I am working and my work is a hindrance & 0.1068 & 0.7379 & 0.1553 & 2.2718 \\
\hline 10. I cannot afford to buy subject requirements & 0.1068 & 0.5728 & 0.3204 & 2.1068 \\
\hline
\end{tabular}

Table 2. On the part of the teacher.

\begin{tabular}{lcccc}
\hline \multicolumn{1}{c}{ On the part of the teacher } & Difficult (3) & Moderate (2) & Easy (1) & Mean \\
\hline 1. I can't understand the teacher's explanation & 0.7777 & 0.6505 & 0.2718 & 2.0388 \\
2. Teacher explain the lessons very fast & 0.1165 & 0.5534 & 0.3300 & 2.1360 \\
3. Teachers are lack of instructional materials & 0.1068 & 0.3010 & 0.5922 & 1.8350 \\
4. Teachers don't give exercises & 0.0582 & 0.5534 & 0.3883 & 1.8447 \\
5. Assignments given are very long & 0.2233 & 0.5340 & 0.2427 & 2.6505 \\
6. Teacher shows favoritism & 0.0777 & 0.3107 & 0.6117 & 1.6990 \\
7. Teacher do not have enough reference material & 0.680 & 0.4175 & 0.5146 & 1.7573 \\
8. Teacher uses lecture method & 0.1262 & 0.5340 & 0.3340 & 2.1650 \\
9. Teacher cannot discipline the class & 0.1068 & 0.5437 & 0.3495 & 2.0777 \\
10. Teacher don't answer the questions of the students & 0.0874 & 0.2913 & 0.6214 & 1.7282 \\
\hline
\end{tabular}

Furthermore, as reflected on the table, it has been noted that teachers explained the lessons very fast with mean score of 2.136, assignments given are very long with 2.6505 mean score and most of the students cannot understand the teacher's explanation with mean score of 2.0388. Moreover, teachers do use only the lecture method and cannot discipline the class well having mean score of 2.1650 and 2.0777, respectively. Teachers do not give exercises, lack of instructional materials and do not have enough reference materials with 1.8447, 1.8350 and 1.7573 mean score, respectively. Teachers do not answer student's questions having 1.7282 mean score. These results implied further that students cannot perform well in the seven areas of learning resulting to low performance level. 


\section{Conclusions}

Based on the results, the researchers found out that the performance level of the students was very low without mastery. Most of the students had no background on the seven areas which resulted to their very low performance. Results show that students do not perform well specially on the application of word problems followed by special product and factoring, equations and radicals.

Results also show that the teachers give a very long assignments to the students in which most of the students do not performed well because they do not have enough referenced materials to use in doing their assignments. Furthermore, teachers explain the lessons very fast in which most of the students do not understand well on the teacher's explanations. The researchers therefore conclude that teachers will realize that there is a need to take into consideration the needs in coping up those lessons where most students have difficulty to be able to enhance their performance in learning college algebra. It is further concluded that teachers should device other effective teaching strategies to help students learn certain subject areas. Also, most of the respondents were deficient in the application of word problems, special products, factoring, equations, and radicals. So, teachers should further discuss those lessons and encourage peer tutoring.

\section{Recommendation}

Based on the results of the study, the researchers would like to recommend that:

1) Teachers would realize the needs of the students in coping up those lessons having difficulty.

2) Teachers would also device effective teaching strategies in college algebra.

3) Students would also take part in doing their task as a student and also take their part during discussion considering that it is a mathematics subject.

4) Future researchers would explore more other effective teaching methods, strategies and techniques in mathematics specifically in mathematics.

\section{References}

[1] Marcus du (2010) A Brief History of Mathematics: 10. Nicolas Bourbaki, BBC Radio 4. 21. http://enu.kz/repository/repository2012/mathematics.pdf

[2] Zulueta, F.M. and Guimbatan, K. (2002) Teaching Strategies and Educational Alternatives. Academic Publishing Corporation, Manila.

[3] Lambdin, D.V. (2003) Benefits of Teaching through Problem Solving. 11.

[4] Anderson, J. (2015) Identifying Problem Solving in School Mathematics. https://www.mav.vic.edu.au/files/conferences/2008/Anderson/AndersonJ2008.doc

[5] Okello, N.P. (2010) Learning and Teaching College Algebra at University Level: Challenges and Opportunities. Africa: Journal of Language, Technology and Entrepreneurship, 2. http://www.ajol.info/index.php/jolte/article/view/51999 